\title{
MIĘDZYNARODOWA KONKURENCYJNOŚĆ SIECI POPYTU - INNOWACJE POPRZEZ CLOUD COMPUTING
}

\section{Wprowadzenie}

Według M. Christophera to nie przedsiębiorstwa, ale łańcuchy dostaw konkurują. We współczesnych uwarunkowaniach gospodarczych w miejscu łańcuchów dostaw coraz częściej pojawiają się międzynarodowe sieci popytu. Są to złożone, globalne struktury przepływu towarów, informacji i pieniędzy trudne do zarządzania przez pojedyncze przedsiębiorstwa będące dotychczas liderami łańcuchów. Naprzeciw wyzwaniom tworzenia i zarządzania globalnymi sieciami popytu o elastycznych oraz adaptacyjnych strukturach odpowiadających oczekiwaniom konsumentów wychodzi cloud computing. Jest to rozwiązanie, które, będąc swoistym ogniwem pomiędzy technologią a biznesem, w innowacyjny sposób łączy problematykę poprawy konkurencyjności międzynarodowych sieci dostaw przy jednoczesnym wsparciu rozwoju pojedynczych podmiotów gospodarczych bez względu na ich wielkość i skalę działania. Chmura obliczeniowa jest podstawą rozwoju gospodarki współdzielenia i współpracy (sharing economy), masowej personalizacji, wszystkich sieci społecznościowych, inteligentnych miast (smart city), jak równicż systemów infrastruktury informatycznej i komunikacyjnej poszczególnych przedsiębiorstw oraz wspomnianych międzynarodowych łańcuchów dostaw. Celem artykułu jest prezentacja możliwości wykorzystania modelu cloud computing we wsparciu rozwoju innowacji w zarządzaniu międzynarodowymi sieciami dostaw sterowanymi w czasie rzeczywistym popytem klientów rozproszonych w skali globalnej. W artykule poszukiwana będzie odpowiedź na pytanie, czy cloud computing jest innowacją, czy raczej narzędziem do wdrażania innowacji i jaki jest zakres wpływu jego wykorzystania na poziom innowacyjności międzynarodowych sieci popytu. Tym samym w pierwszej kolejności podjęta zostanie próba określenia czynników międzynarodowej konkurencyjności sieci popytu,

\footnotetext{
* Kolegium Nauk o Przedsiębiorstwie, Szkoła Główna Handlowa w Warszawie.
} 
aby w dalszej części opracowania wskazać możliwość ich wsparcia poprzez zastosowanie chmury obliczeniowej w kontekście różnego rodzaju innowacji.

\section{Współczesne sieci dostaw - wyzwania międzynarodowej konkurencyjności}

Łańcuch dostaw to sieć organizacji zaangażowanych, poprzez powiązania $\mathrm{z}$ dostawcami i odbiorcami, w różne procesy oraz działania, które tworzą wartość w postaci produktów i usług dostarczanych konsumentom. Zarządzanie łańcuchem dostaw to zarządzanie stosunkami (partnerstwo) z dostawcami i odbiorcami oraz klientami w celu dostarczenia najwyższej wartości dla klienta po najniższych kosztach dla całego łańcucha ${ }^{1}$. Takie podejście wymaga konfrontacji interesu pojedynczego przedsiębiorstwa $z$ interesem wszystkich firm współpracujących $w$ ramach łańcucha. Działania w takim łańcuchu są nakierowane na szybką reakcję na zmiany w poziomie popytu rozproszonego w skali globalnej. Ponadto współczesne łańcuchy dostaw charakteryzują się złożonością i mnogością relacji zaangażowanych partnerów. Dlatego bardziej adekwat nym określeniem dla tego zjawiska będzie sieć popytu. Za istotę koncepcji sieci przyjęto, że „sieć przedsiębiorstw stanowi formę organizacji ekonomicznych działań, której celem jest realizacja korzyści w zakresie konkurencji i która charakteryzuje się relacjami kompleksowymi oraz zwrotnymi, raczej kooperacyjnymi niż kompensacyjnymi i stosunkowo stałymi, między prawnie niezależnymi ekonomicznie, jednakże zwykle zależnymi przedsiębiorstwami”2.

Wobec powyższego sieć popytu oznacza zaangażowanie we współpracę wielu zależnych i współzależnych podmiotów gospodarczych koncentrujących swoje działania na dodawaniu wartości poprzez umiejętne odpowiadanie na trudny do przewidzenia i zaplanowania popyt.

Analizowanie konkurencyjności sieci popytu wymaga wyjaśnienia znaczenia i przyjętego podejścia. „Konkurencja ma miejsce wówczas, gdy przedsiębiorstwa dążąc do realizacji określonych celów, muszą rywalizować między sobą. Projektując działania podejmowane dla osiągnięcia celów, powinny uwzględniać uwarunkowania wewnątrzorganizacyjne oraz zewnętrzne, w tym zwłaszcza te, które zmieniają

1 M. Christopher, Logistics and Supply Chain Management, Pearson, London 2016, s. 13-14.

2 K. Poznańska, Sieci wspótpracy a innowacyjność przedsiębiorstw, [za:] J. Sydow, Mitbestimmung und neue Unternehmensnetzwerke, [w:] J. Sydow, C. Wirth, Arbeit, Personal und Mitbestimmung in Unternehmungsnetzwerken, Verlag Hampp, München-Mering 1999, s. 79, [w:] Granice strukturalnej złożoności organizacji, red. A. Sopińska, S. Gregorczyk, Oficyna Wydawnicza SGII, Warszawa 2014, s. 152. 
warunki konkurowania”3. W najprostszym ujęciu na konkurencyjność, czyli możliwość rywalizacji, wpływa ograniczanie kosztów i poprawa jakości oferowanych produktów (towarów i/lub usług), czyli proponowanie wartości, które spełniają oczekiwania i potrzeby klientów. Zgodnie z teorią strategii konkurowania, według M. Portera, konkurencyjność może być osiągana poprzez niskie koszty, zróżnicowanie oferty bądź koncentrację na niszowych rozwiązaniach ${ }^{4}$. Strategie te są stosowane niezależnie lub jednocześnie, stanowiąc punkt odniesienia do koncentracji działań organizacji. Niewątpliwie ograniczanie kosztów jest jednym ze stałych elementów prowadzenia działalności gospodarczej bez względu na to, czy jest to przedsiębiorstwo oferujące mnogość produktów, czy koncentrujące się na pojedynczym segmencie rynku. Z racji tego, że w dzisiejszych czasach nie przedsiębiorstwa, ale całe łańcuchy konkurują, w tych trzech perspektywach można także analizować konkurencyjność międzynarodowych sieci popytu. Szeroka gama produktów dostępnych w międzynarodowych sieciach popytu to przede wszystkim możliwość zbudowania szybko reagujących i gęstych kanałów dystrybucji zapewniających utrzymywanie zapasów na optymalnym kosztowo poziomie. Sieć popytu konkurująca w obszarze rozwiązań niszowych natomiast wymaga stałej obserwacji zmian w obszarze innowacji decydujących o jakości dostarczanego produktu, jest to także możliwość szybkiej adaptacji tego rozwiązania i współpracy z pojedynczymi dostawcami rozproszonymi w międzynarodowej skali.

Podstawą do osiągania konkurencyjności uwarunkowanej powyższymi czynnikami jest jakość zarządzania logistycznego ${ }^{5}$. Wynika to $z$ faktu, że logistyka jest swoistą platformą i zakłada podejście planistyczne umożliwiające organizowanie działań w sposób adekwatny do przyjętej strategii konkurowania. Zarządzanie siecią popytu opiera się na tej platformie i stara się osiągnąć powiązania i koordynację pomiędzy procesami przebiegającymi w przestrzeni całej sieci. Nie jest to możliwe bez osiągnięcia pewnych cech decydujących o sukcesie w rywalizacji pomiędzy sieciami dostaw będącymi współcześnie konkurentami.

Niewątpliwym czynnikiem umożliwiającym konkurowanie sieciami popytu jest ich integracja. Organizacje w sieci są powiązane i wspólzależne, a ograniczanie działań jedynie do kontroli własnego zaopatrzenia i sprzedaży może okazać się

\footnotetext{
3 M.J. Stankiewicz, Konkurencyjność przedsiębiorstwa. Budowanie konkurencyjności przedsiębiorstwa w wartnkach globalizacji, TNOIK, Toruń 2002, s. 66.

4 M. Porter, Strategia konkurencji. Metody analizy sektorów i konkurentów, PWE, Warszawa 1994, s. $50-55$.

5 Czyli „zarządzania procesem strategicznego kierowania zaopatrzeniem, przemieszczaniem i składowaniem surowców, produkcji w toku i wyrobów gotowych (oraz odpowiednich przepływów informacyjnych) w przedsiębiorstwie i w jego kanalach marketingowych w taki sposób, aby obecna i przyszla rentowność była maksymalizowana przez efektywne kosztowo realizowanie zamówień". M. Christopher, op.cit., s. 2.
} 
w efekcie dla całego systemu krótkowzroczne. Integracja poprzez zarządzanie przepływami w różnych kierunkach sieci popytu jest bowiem podejściem systemowym. Uwzględnia ono współzależności podejmowanych decyzji przez poszczególne ogniwa i kontroluje jakość efektu końcowego objawiającego się w globalnych kosztach logistycznych, decydując o przewadze konkurencyjnej całego systemu, czyli sieci popytu.

Konkurencyjne sieci popytu potrzebują zatem integratora, który bezsprzecznie jest katalizatorem zmian w systemie. Jest nim najczęściej lider kształtujący pewne zachowania i narzucający określone standardy współpracy nie tylko w relacjach bezpośrednich z partnerami, ale także w relacjach dostawców i klientów dalszych rzędów. W literaturze przedmiotu tacy integratorzy noszą też często miano „orkiestratorów” (orchestrator). Jest to funkcja związana $z$ odpowiedzialnością za organizowanie przepływów w ramach danego łańcucha dostaw, tu: sieci popytu. Wśród różnych definicji orkiestratora wskazuje się, ze jest on niezhierarchizowanym koordynatorem; neutralnym dostawcą zewnętrznym (third-party), który koncentruje się na rozwoju architektury systemu; tym, który organizuje współpracę przedsiębiorstw i dostarcza rozwiązania konsumentom; kierownikiem odpowiedzialnym za tworzenie sieci wartości; koordynatorem sieci dostaw; tym, który efektywnie wykorzystuje zasoby partnerów w celu zwiększania działań w łańcuchu wartości, a także firmą zaangażowaną w działania związane z zarządzaniem, koordynowaniem skupionym na tworzeniu sieci wartoścí. W publikacjach podkreśla się kluczową rolę takiego koordynatora dla tworzenia efektywnego i konkurencyjnego łańcucha dostaw. W relacjach partnerskich istnicje możliwość, aby tego typu koordynatorem działań był także lider łańcucha dostaw zarządzający przepływami pomiędzy zintegrowanymi podmiotami. Istotą jest umiejętność synchronizacji informacji napływających jednocześnie z różnych poziomów sieci popytu w taki sposób, aby ich wykorzystanie (jednoczesne przez różne poziomy tej sieci) było najbardziej efektywne, czyli skracało czas reakcji sieci na trudny do przewidzenia popyt zgłaszany przez konsumentów w skali międzynarodowej w czasie rzeczywistym. W efekcie występuje zbieżność poziomu podaży zasobów wobec poziomu aktualnego popytu (często o fluktuującym charakterze).

Integracja i przywództwo w sieci łączy się także w bezpośredni sposób z przyjęciem określonej strategii konkurowania, która narzuca poszczególnym partnerom zakres zachowań kształtujących finalną wartość oferowaną konsumentowi. W efekcie konsument rozwazający decyzję o zakupie podejmuje ją, posiadając już pewne konkretne oczekiwania, które identyfikuje $\mathrm{z}$ produktem dostarczanym przez daną sieć popytu. Oczekiwania te są konsekwencją jego doświadczenia wynikającego

6 Z.G. Zacharia, N.R. Sanders, N.W. Nix, The Emerging Role of the Third Party Logistics Provider (3PL) as an Orchestrator, „Journal of Business Logistics” 32(1), 2011, s. 44. 
z komunikowanych przez sieć standardów. Te standardy mogą także stymulować lojalność klientów, stając się dla przedsiębiorstw zaangażowanych we współpracę w sieci wartością nadrzędną i swoistym drogowskazem.

\section{Istota innowacji wobec konkurencyjności sieci dostaw}

Zarządzanie złożoną, globalną siecią popytu rodzi szereg wyzwań dla ich liderów (orkiestratorów). Ma to miejsce szczególnie wtedy, gdy aspirują oni do miana innowatorów. Innowacje bowiem, odgrywając kluczową rolę w procesie pozyskiwania i utrzymywania relacji z klientem, stanowią istotną wartość i są główną siłą napędową konkurencyjności. Mogą one być wdrażane we wszystkich wymienionych wcześniej strategiach. Powszechnie cytowana definicja innowacji z Podręcznika Oslo OECD mówi, że innowacja jest to wdrożenie nowego lub istotnie ulepszonego produktu (towaru lub usługi), nowego lub istotnie ulepszonego procesu, nowej metody marketingu lub nowej metody organizacji w zakresie praktyk biznesowych, organizacji miejsca pracy bądź relacji ze środowiskiem zewnętrznym ${ }^{7}$.

W podręczniku wyróżniono cztery typy innowacji: innowacje w obrębie produktów, procesów, innowacje marketingowe oraz innowacje organizacyjne. Innowacja produktowa to wprowadzenie wyrobu lub usługi, które są nowe lub znacząco udoskonalone w zakresie swoich cech lub zastosowań. Zalicza się tu znaczące udoskonalenia pod względem specyfikacji technicznych, komponentów i materiałów, wbudowanego oprogramowania, łatwości obsługi lub innych cech funkcjonalnych.

Innowacja procesowa, czyli innowacja w obrębie procesu jest to wdrożenie nowej lub istotnie ulepszonej metody produkcji lub dostawy. Obejmuje w szczególności istotne zmiany w stosowanych technikach, wyposażeniu i oprogramowaniu. Ich celem jest głównie ograniczanie kosztów jednostkowych produkcji lub dostawy, zwiększenie jakości, a także produkcja nowych lub istotnie ulepszonych produktów. Metody dostawy dotyczą natomiast wyposażenia, oprogramowania i techniki/technologii związanych z zaopatrzeniem i dystrybucją produktów finalnych. Do innowacji procesowych zaliczane są również nowe lub istotnie ulepszone metody tworzenia oraz świadczenia usług. Może to obejmować istotne zmiany w sprzęcie i oprogramowaniu stosowanych w przedsiębiorstwach usługowych oraz zmiany procedur i technik używanych do świadczenia usług.

7 OECD, Oslo Manual. Guidelines for Collecting and Interpreting Technological Innovation Data, $3^{\text {rd }}$ ed., OECD/Eurostat, Paris 2005, s. 46. 
Innowacja marketingowa to wdrożenie nowej metody marketingowej wiążącej się ze znaczącymi zmianami w projekcie/konstrukcji produktu lub w opakowaniu, dystrybucji, promocji czy strategii cenowej.

Natomiast innowacja organizacyjna to wdrozenie nowej metody organizacyjnej w przyjętych przez firmę zasadach działania, w organizacji miejsca pracy lub $\mathrm{w}$ stosunkach $\mathrm{z}$ otoczeniem. Wyróżnikiem innowacji organizacyjnej w zestawieniu $z$ innymi zmianami organizacyjnymi w firmie jest zastosowanie takiej metody organizacyjnej ( $w$ przyjętych przez firmę zasadach działania, w organizacji miejsca pracy czy w stosunkach z otoczeniem), która nie była dotychczas stosowana w danej firmie i która wynika ze strategicznych decyzji podjętych przez jej kierownictwo. Innowacje organizacyjne polegają na wdrażaniu nowych metod organizowania rutynowych działań i procedur regulujących pracę firmy ${ }^{8}$.

Z punktu widzenia zarządzania siecią popytu $z$ wykorzystaniem innowacji niewątpliwie interesująca będzie innowacja procesowa i organizacyjna. W bezpośredni sposób mogą one bowiem wpływać na jakość oferowania towarów, czyli zarządzania przepływami w sieci popytu, poprawiając w znaczący sposób ich konkurencyjność. K. Poznańska wyróżnia pojęcie sieci innowacyjnych, które stanowią specyficzny rodzaj sieci przedsiębiorstw, nie są całkowicie zależne od transakcji, są raczej ograniczone czasowo i związane z projektem innowacyjnym. Sieci takie zorientowane są na rozwiązanie problemu i w związku z tym skoncentrowane są na sprostaniu nierutynowym, kompleksowym i indywidualnym zadaniom w warunkach dużej zmienności otoczenia9. Warto jednak zaznaczyć, że współczesne warunki konkurowania narzucają swoisty rygor elastyczności i adaptacyjności, tym samym organizacje wspótpracujących w ramach sieci przedsiębiorstw powinny być nastawione na działania o nietrwałym, zdarzeniowym charakterze. Takie sieci popytu nacechowane są innowacjami poprzez stałe dążenie do utrzymania swej organizacji w pełnej gotowości do bieżącego odpowiadania na nieustanne zmiany.

Ponadto w literaturze przedmiotu wyróżnia się innowacje otwarte i zamknięte. Założeniem innowacji otwartej jest to, że przedsiębiorstwa mogą korzystać nie tylko $z$ wyników własnych badań, lecz także $z$ rozwiązań zaproponowanych przez inne jednostki ${ }^{10}$. Jej istotą jest więc współpraca pomiędzy organizacjami. W przypadku innowacji zamkniętych mowa jest o wszystkich działaniach związanych z tworzeniem innowacji wewnątrz firmy (od kreowania pomysłów, rozwoju koncepcji produktu aż po jego wprowadzenie na rynek). Analizując sieci popytu, warto zatem rozważać

Ibidem, s. 49-54.

9 K. Poznańska, op.cit., s. 152-153.

10 D. Fasnacht, Open Innovation: The New Business Paradigm, Springer, Berlin-I Ieidelberg 2009, s. 88-93. 
kontekst innowacji otwartych mogących wspierać ich globalną konkurencyjność. Dzielenie się wiedzą w tym obszarze staje się kluczem i jednocześnie codziennością we wspólpracy.

\section{Digitalizacja jako trend kształtujący innowacje we współczesnych sieciach popytu}

Współczesne główne trendy wywierające znaczący wpływ i zmieniające sposób zarządzania sieciami popytu związane są z szeroko rozumianą technologią informatyczną i komunikacyjną (Information and Communication Technology, ICT). Według definicji GUS „Pod pojęciem technologii informacyjnych i komunikacyjnych (zwanych zamiennie technologiami informacyjno-telekomunikacyjnymi, teleinformatycznymi lub technikami informacyjnymi) kryje się rodzina technologii przetwarzających, gromadzących i przesyłających informacje w formie elektronicznej. Węższym pojęciem są technologie informatyczne (IT), które odnoszą się do technologii związanych $z$ komputerami i oprogramowaniem, niezwiązanych jednak z technologiami komunikacyjnymi i dotyczącymi sieci. Rozwój tych technologii sprawia, że oba pojęcia stają się coraz bardziej spójne, będąc przy tym motorem rozwoju cywilizacyjnego, społecznego i gospodarczego" ${ }^{\prime 11}$. IT to technologie związane ze zbieraniem, przechowywaniem, przetwarzaniem, przesyłaniem i prezentacją informacji (tj. tekstów, obrazów i dźwięku), obejmujące w szczególności technologie komputerowe (sprzęt i oprogramowanie) i komunikacyjne ${ }^{12}$. Dostarczają one narzędzi, za pomocą których można pozyskiwać informacje, selekcjonować je, analizować, przetwarzać i przekazywać odbiorcom.

W efekcie rozwoju wykorzystywania możliwości ICT powstały i błyskawicznie upowszechniły się rozwiązania wspomagające zarówno obszar zarządzania podmiotami gospodarczymi, sektorem publicznym, jak i zyciem prywatnym. Do najważniejszych zjawisk w tej sferze należą sieci społecznościowe (social media), usługi mobilne (mobile), zaawansowana analityka biznesowa (analitics) i chmura obliczeniowa (cloud computing) $)^{13}$.

\footnotetext{
11 J. Berezowska, M. Kamińska, M. Kwiatkowska, E. Niewiadomska, B. Szczepańska, M. Wegner, Spoteczenistwo informacyjne w Polsce. Wyniki badań statystycznych z lat 2006-2010, GUS, Warszawa 2010, s. 7.

12 stat.gov.pl/metainformacje/slownik-pojec/pojecia-stosowane-w-statystyce-publicznej/770, pojecie. html [dostep 25.09.2016].

13 G. Ilanifan, A. Sharma, C. Newberry, The Digital Supply Network. A New Paradigm for Supply Chain Management, Accenture Strategy, 2014, s. 4.
} 
Kumulacja wykorzystania tych zjawisk w obszarze zarządzania prowadzi do rozwoju tzw. czwartej ery zmian - Przemysł 4.0 (Industry 4.0) - jest napędzana wzrostem potrzeby łączności, orientacją na usługi, wykorzystywaniem zaawansowanych technologii w materiałach i procesach, rozwojem zaawansowanych sieci współpracy oraz rozwojem sieci połączonych zaawansowanych urządzeń produkcyjnych sterowanych przez komputery, które łączą środowisko cy frowe z fizycznym. Zmiany te obejmują całe sieci popytu od producentów surowców po konsumentów we wszystkich kierunkach przepływu towarów (jak również informacji i pieniędzy), wpływając na wszystkie sfery prowadzenia działalności gospodarczej ${ }^{14}$.

Należy podkreślić, że punktem odniesienia dla możliwości rozwoju Industry 4.0, sieci społecznościowych, usług mobilnych czy analityki biznesowej jest cloud computing. Stanowi on, obok internetu, katalizator współczesnych zmian wirtualizacji i digitalizacji przestrzeni biznesowej oraz prywatnej. Przy czym, ze względu na swoje właściwości, cloud computing jest swoistym ogniwem pomiędzy zdefiniowaną technologią a zarządzaniem podmiotami gospodarczymi.

Cloud computing jest usługą umożliwiającą dostęp przez internet do współdzielonej puli zasobów (np. sieci, serwerów, pamięci masowych, oprogramowania), które są konfigurowalne, dostępne „na życzenie”, mogą być szybko alokowane i zwalniane przy minimalnej interakcji użytkownika usług, umożliwiając elastyczne zwiększanie lub zmniejszanie zasobów w zależności od bieżącego zapotrzebowania podmiotu ${ }^{15}$. Do głównych właściwości modelu cloud computing należą ${ }^{16}$ :

- skalowalność, czyli możliwość dynamicznego przydzielania i zwalniania zasobów w zależności od bieżącego popytu bez konieczności utrzymywania własnej infrastruktury, co ma miejsce w tradycyjnym rozwiązaniu, w którym podmiot jest właścicielem aktywów;

- skrócenie czasu przetwarzania danych, ponieważ jest to wykonywane jednocześnie na znaczącej liczbie serwerów często rozproszonych geograficznie;

- zależność poziomu płatności od faktycznie wykorzystanej mocy obliczeniowej, przepustowości łącza internetowego i przestrzeni dyskowej;

- dostępność usługi za pośrednictwem internetu i standardowych urządzeń sieciowych (komputer lub inne urządzenia mobilne);

- współdzieloność infrastruktury - wielu klientów korzysta wspólnie z infrastruktury fizycznej, platformy technologicznej czy też aplikacji, co wpływa na korzyści skali;

14 Industry 4.0. An Introduction, Deloitte, The Netherlands 2015, s. 3.

15 P. Mell, T. Grance, The NIST Definition of Cloud Computing, Special Publication 800-145, Recommendations of the National Institute of Standards and Technology, NIST, Gaithersburg 2011.

16 K. Nowicka, Cloud computing a koszty transakcyjne, [w:] Uwarunkowania zmian kosztów transakcyjnych, red. R. Sobiecki, J.W. Pietrewicz, Oficyna Wydawnicza SGI, Warszawa 2011, s. 231-254. 
- dostępność usług „na żądanie” w jednostkach zależnych od usługi - jednostką może być użytkownik, ilość przesłanych danych, transakcja albo kombinacja tych wartości;

- możliwość samodzielnego korzystania z usługi, dzięki czemu użytkownicy mogą samodzielnie instalować i konfigurować oprogramowanie.

W literaturze związanej z zarządzaniem i technologiami informatycznymi wskazuje się na istnienie rozproszonych wartości (łańcuchów wartości) wynikających z rozwoju rynku komputerów, rynku oprogramowania i rynku usług ${ }^{17}$. Cloud computing łączy te lańcuchy wartości, umożliwiając jednoczesne stosowanie najnowszych rozwiązań technologicznych z zakresu sprzętu, oprogramowania i zastosowania modelu usługi jako sposobu dostępu do tych rozwiązań.

Kumulacja cech i właściwości najważniejszych zjawisk digitalizujących współczesne przedsiębiorstwa coraz częściej przenosi je w świat e-biznesu. Także sieci popytu podlegają tym przemianom, przybierając formę sieci wirtualnych. To one będą stanowiły o przyszłym kształcie modelu realizacji zakupów i zachowania konsumentów na rynku (coraz częściej w wymiarze rynku wirtualnego).

\section{Cloud computing jako punkt wyjścia do innowacji międzynarodowych sieci popytu}

Wirtualne sieci popytu są jedną z form możliwości rozwoju współczesnego przedsiębiorstwa zmieniającego się pod wpływem zastosowania chmury obliczeniowej. Potencjał kumulacji w zasadzie nieograniczonej ilości danych i jednoczesny dostęp wszystkich ogniw (i innych interesariuszy) sieci popytu do informacji w czasie rzeczywistym stanowi narzędzie kształtujące w bezpośredni sposób poziom jej innowacji, a zatem konkurencyjność w skali globalnej. Innowacje te mają różny charakter i zakres wpływu. Jednocześnie, ze względu na efekt dyfuzji innowacji, implementacja chmury obliczeniowej przez pojedyncze przedsiębiorstwo może odgrywać istotną rolę $w$ organizacji, procesach, marketingu, a także oferowanych produktach przez pozostałych partnerów w sieci. Tym samym uzyskiwane są w tego typu sieciach efekty mnożnikowe wynikające m.in. $z$ dzielenia się zasobami (głównie wiedzą, ale także potencjałem dostępnej infrastruktury) zarówno po stronie dostawców realizujących

17 T. Kasprzak, Biznes i technologie informacyjne. Perspektywa integracji strategicznej, Nowy Dziennik Sp. z 0.0. i Katedra Informatyki Gospodarczej i Analiz Ekonomicznych, UW, Warszawa 2003, s. 92-93. 
Zamówienia w sieci popytu, jak i klientów, którzy za pomocą sieci społecznościowych $^{18}$, jako innowacyjnego kanału marketingowego, kreują wartość dla owych sieci.

Niewątpliwie największą rolę w tworzeniu innowacji w sieciach popytu ze względu na wykorzystanie chmury obliczeniowej mają platformy informatyczne dostępne poprzez internet. Tworzona $w$ ten sposób innowacja procesowa polega na automatyzacji dotychczasowych działań i operacji, bądź ich całkowitej eliminacji z procesu. Istotnym „skutkiem ubocznym”, choć w pewnych uwarunkowaniach postrzeganym jako korzyść, jest wykluczenie nawet całych grup ogniw stanowiących dotychczas pośredników, a w nowym rozwiązaniu niebędących w stanie dodawać istotnych wartości. W efekcie skracany jest czas reakcji sieci na zmiany w popycie, a dostęp do jej zasobów niemal w czasie rzeczywistym pozwala na taką konfigurację, która umożliwia elastyczne dopasowywanie struktury zasobów do zindywidualizowanych potrzeb. To rozwiązanie wychodzi naprzeciw oczekiwaniom masowej personalizacji (kastomizacji). Wyniki badania „Harvard Business Review” wskazują, że zastosowanie chmury obliczeniowej według $53 \%$ badanych wpływa na możliwość „skalowania biznesu", czyli dostarczania rozwiązań dopasowanych do aktualnych potrzeb w sposób elastyczny, bez konieczności zamrażania kapitału w aktywa trwałe. 50\% respondentów wskazało możliwość szybkiego dopowiadania na pojawiające się szanse dzięki wykorzystaniu chmury obliczeniowej, kolejne 43\% podkreśliło ograniczenie kosztów związane $\mathrm{z}$ tym rozwiązaniem ${ }^{19}$.

W sferze innowacji produktowych warto zastanowić się, w jakim stopniu właściwości chmury obliczeniowej mogą wpływać na znaczące zmiany udoskonalające lub stanowiące o możliwości oferowania nowych rozwiązań. Poza zmianą w obrębie jego cech (np. zastosowanie telefonu jako nawigatora w terenie, a nie urządzenia do wykonywania połączeń telefonicznych) pojawiają się zmiany związane z możliwością dostępu do dużych zbiorów informacji i w związku z tym dostępu do samego produktu. W efekcie pojawily się rozwiązania typu $\Lambda$ irBnB, Uber, Taskrabbit, czy Bla-bla car, które w oparciu o cloud computing są w stanie rekonfigurować dotychczasowe zależności w sieciach dostaw i w innowacyjny sposób zmieniać całe sektory gospodarki.

Nie tylko pojedyncze przedsiębiorstwa, ale i sieci popytu konkurujące w skali międzynarodowej, implementując rozwiązania chmury obliczeniowej w swoich modelach biznesowych, są w stanie dokonać innowacji organizacyjnej. Model biznesu oparty na platformie internetowej wykorzystujący chmurę obliczeniową jest bowiem biegunowo odmienny od modelu przedsiębiorstwa lub łańcucha dostaw

18 Wszystkie wspólczesne sieci społecznościowe oparte są na modelu chmury obliczeniowej.

19 Badanie przeprowadzone na grupie 537 respondentów $Z$ dużych firm (powyżej 1000 zatrudnionych) w $2014 \mathrm{r}$. Harvard Business Review Analytic Services, The Digital Transformation of Business, „Harvard Business Review" 2015, s. 6 . 
(także sieci popytu) opartego na posiadaniu zasobów własnych. Jest on nakierowany na świadczenie usług, a dokładnie na upowszechnianie informacji na temat dostępnych zasobów, których funkcjonalność można nabyć w formie usługi. Jest to podstawą osiągania korzyści skali właścicieli tychże zasobów, którzy udostępniają je zainteresowanym klientom na bardzo szeroką skalę - obszar dostępu do internetu. Tym samym modele biznesu stają się elastyczne, adaptacyjne i „łatwo manewrowalne" przez integratora sieci popytu.

Ponadto zastosowanie chmury obliczeniowej warto rozważać w ujęciu istoty innowacji otwartej. Przejawia się ona tu poprzez dostęp do wiedzy poszczególnych partnerów zaangażowanych w sieć popytu w czasie rzeczywistym. Są oni zatem w stanie wykorzystywać informacje i w efekcie podejmować decyzje w krótszym czasie niż konkurencyjne sieci. Niewątpliwie ważna jest jednak chęć dzielenia się owymi informacjami, a zatem poziom zaufania, którym obdarzają się partnerzy, co jest cechą niezależną wobec analizowanego tematu ${ }^{20}$.

Dodatkowo L. Willcocks, W. Venters i E. Whitley wskazują trzy poziomy innowacji, na które oddziałuje zastosowanie chmury obliczeniowej. Są nimi ${ }^{21}$ :

- poziom operacyjny związany z IT i ze zmianami wynikającymi z dostępu do infrastruktury informatycznej przez przedsiębiorstwo, co lączy się także ze zmianami personalnymi (przy czym nie chodzi tylko o redukcję zatrudnienia w tym obszarze, ale o sposób postrzegania menedzerów IT jako współtworzących metody realizacji strategii firmy);

- poziom innowacji procesów biznesowych;

- poziom innowacji produktowych (w tym także umożliwiających wchodzenie na nowe rynki zbytu, czyli rozwój umiędzynaradawiania przedsiębiorstw).

Jednocześnie wartym analizy aspektem jest także wpływ chmury obliczeniowej na konkurencyjność sieci popytu poprzez innowacje w kontekście jej zrównoważonego rozwoju. Wszystkie bowiem obszary zarządzania logistyką i łańcuchem dostaw opisane na wstępie podlegają zmianom wynikającym z implementacji chmury obliczeniowej. Są to np. możliwość wyboru transportu multimodalnego (wykorzystując np. internetowe gieldy transportowe) czy ograniczania utrzymywania poziomu zapasów u poszczególnych partnerów wspólpracujących w sieci (ze względu na dostęp do biezących informacji) wpływające w efekcie nie tylko na aspekty ekonomiczne,

20 Problematyka bezpieczeństwa danych, która towarzyszy rozważanym decyzjom związanym z implementacją chmury obliczeniowej, jest przedmiotem analizy np. w: K. Nowicka, Cloud computing - wyzwania przedsiębiorczości nowych mediów, [w:] Przedsiębiorczość nowych mediów. Analiza modeli biznesowych firm internetowych, red. I.K. Hejduk, Oficyna Wydawnicza SGII, Warszawa 2013, s. 149-174.

21 L.P. Willcocks, W. Venters, E.A. Whitley, Cloud sourcing and innovation: slow train coming? „Strategic Outsourcing: An International Journal" Vol. 6, No. 2, 2013, s. 187. 
ale i proekologiczne. Rosnąca świadomość klientów wobec struktury kosztów w łańcuchu dostaw (np. miejsc produkcji, jakości surowców czy marż pośredników) również nie będzie pozostawała bez znaczenia dla decyzji o działaniach wywierających niekorzystny wpływ na środowisko naturalne. Umiejętność dostrzeżenia wpływu chmury obliczeniowej na działania przedsiębiorstw w kontekście ich zrównoważonego rozwoju może stać się rzeczywistym obszarem konkurowania, a nie jedynie działaniem PR-owym.

Wpływ chmury obliczeniowej na innowacje i współczesne zarządzanie przedsiębiorstwem bądź sieciami jest zdecydowanie bardziej dalekosiężny niż wskazane tu przykłady. Jest to bowiem rozwiązanie, dzięki któremu istnieje możliwość rozwoju niemal wszystkich pozostałych narzędzi wspierających lub tworzących nową przestrzeń konkurowania poprzez innowacje. Należą do nich rozwój mobilności, internetu rzeczy, sieci społecznościowych, zaawansowanej analityki biznesowej czy w końcu całego nowego zjawiska - gospodarki współdzielenia (sharing economy) ${ }^{22}$. Ta swoista dyfuzja innowacji ma swoje źródło we właściwościach chmury obliczeniowej i umiejętnym ich zastosowaniu dobranym na miarę skali potrzeb - bądź przez pojedyncze przedsiębiorstwa, bądź przez międzynarodowe sieci popytu. W obydwu przypadkach jednak organizacje te mogą czerpać korzyści ze względu na innowacje towarzyszące implementacji chmury obliczeniowej.

Cloud computing jako taki jest innowacją polegającą na nowym, powszechnym dostępie do mocy obliczeniowej, który to dostęp dotyczy kosztów, miejsca i czasu. W efekcie jest on w zasięgu posiadania każdej organizacji bez względu na jej wielkość, zasobność czy skalę działania. Jednak istotą innowacyjności tego rozwiązania są efekty spowodowane wdrożeniem chmury obliczeniowej. Mogą to być zarówno innowacje produktowe, procesowe, marketingowe, jak i organizacyjne. Potencjał ten jest limitowany umiejętnością wykorzystania tego rozwiązania przez podmioty gospodarcze, co ma miejsce także w analizowanych tu sieciach popytu.

\section{Zakończenie}

Cloud computing jako zespół pewnych właściwości wynikających z technologii informatycznych i telekomunikacyjnych oraz sposobu dostępu do nich stanowi

22 K. Nowicka, Cloud computing - wartnek sine qua non Sharing Economy, [w:] Gospodarka wspótdzielenia, red. R. Sobiecki, J.W. Pietrewicz, M. Poniatowska-Jaksch, Oficyna Wydawnicza SGII, Warszawa (w druku1). 
interesujące narzędzie do tworzenia (i wdrażania) innowacji w obszarze produktów, procesów, marketingu i organizacji. Zarządzanie sieciami popytu jest natomiast nastawione na ciągłe udoskonalanie i wprowadzanie konkurencyjnych rozwiązań, nieustannie poszukując innowacji pozwalających wychodzić naprzeciw oczekiwaniom klientów (głównie konsumentów). Jednocześnie sieci popytu, aby wzmacniać swoją pozycję konkurencyjną, powinny charakteryzować się pewnym zbiorem właściwości wspomagających ich pozycję na arenie międzynarodowej. Mowa tu przede wszystkim o integracji, czyli nakierowaniu na osiąganie wspólnych celów i realizację strategii. Niewątpliwym wsparciem umożliwiającym zacieśnianie współpracy nakierowanej na wspólne cele jest lider takiej sieci, czyli jej integrator (nazywany także orkiestratorem). Jego rolą jest przywództwo oparte na umiejętności synchronizacji informacji nakierowanej na wyrównywanie poziomu podaży oferowanej przez całą sieć wobec zgłaszanego jej popytu. Z racji fluktuacji owego popytu niezbędny jest dostęp do informacji od wszystkich partnerów w czasie rzeczywistym. Współczesne rozwiązania $z$ obszaru technologii informatycznych i telekomunikacyjnych, a także im pokrewnych, oferują zbiór interesujących narzędzi, dzięki którym przedsiębiorstwa mogą wprowadzać innowacje w różnych obszarach swojej działalności. Niewątpliwym ich swoistym spoiwem jest chmura obliczeniowa dająca potencjał do rozwoju mobilności, automatyzacji, zaawansowanej analityki czy komunikacji. Stanowi ona tym samym punkt odniesienia do cyfryzacji współczesnych przedsiębiorstw oraz całych sieci popytu.

\section{Literatura}

Berezowska J., Kamińska M., Kwiatkowska M., Niewiadomska E., Szczepańska B., Wegner M., Spoteczeństwo informacyjne w Polsce. Wyniki badan statystycznych $z$ lat 2006-2010, GUS, Warszawa 2010.

Christopher M., Logistics and Supply Chain Management, Pearson, London 2016.

Fasnacht D., Open Innovation: The New Business Paradigm, Springer, Berlin-Heidelberg 2009.

Hanifan G., Sharma A., Newberry C., The Digital Supply Network. A New Paradigm for Supply Chain Management, Accenture Strategy, 2014.

Harvard Business Review Analytic Services, The Digital Transformation of Business, „Harvard Business Review” 2015.

Industry 4.0. An Introduction, Deloitte, The Netherlands 2015.

Kasprzak T., Biznes i technologie informacyjne. Perspektywa integracji strategicznej, Nowy Dziennik Sp. z o.o. i Katedra Informatyki Gospodarczej i Analiz Ekonomicznych, UW, Warszawa 2003. 
Mell P., Grance T., The NIST Definition of Cloud Computing, Special Publication 800-145, Recommendations of the National Institute of Standards and Technology, NIST, Gaithersburg 2011.

Nowicka K., Cloud computing a koszty transakcyjne, [w:] Uwarunkowania zmian kosztów transakcyjnych, red. R. Sobiecki, J.W. Pietrewicz, Oficyna Wydawnicza SGH, Warszawa 2011.

Nowicka K., Cloud computing - warunek sine qua non Sharing Economy, [w:] Gospodarka wspóldzielenia, red. R. Sobiecki, J.W. Pietrewicz, M. Poniatowska-Jaksch, Oficyna Wydawnicza SGH, Warszawa (w druku).

Nowicka K., Cloud computing - wyzwania przedsiębiorczości nowych mediów, [w:] Przedsiębiorczość nowych mediów. Analiza modeli biznesowych firm internetowych, red. I.K. Hejduk, Oficyna Wydawnicza SGH, Warszawa 2013.

OECD, Oslo Manual. Guidelines for Collecting and Interpreting Technological Innovation Data, $3^{\text {rd }}$ ed., OECD/Eurostat, Paris 2005.

Porter M., Strategia konkurencji. Metody analizy sektorów i konkurentów, PWE, Warszawa 1994.

Poznańska K., Sieci wspótpracy a innowacyjność przedsiębiorstw, [za:] J. Sydow, Mitbestimmung und neue Unternehmensnetzwerke, [w:] J. Sydow, C. Wirth, Arbeit, Personal und Mitbestimmung in Unternehmungsnetzwerken, Verlag Hampp, München-Mering 1999, [w:] Granice strukturalnej złożoności organizacji, red. A. Sopińska, S. Gregorczyk, Oficyna Wydawnicza SGH, Warszawa 2014.

Stankiewicz M.J., Konkurencyjność przedsiębiorstwa. Budowanie konkurencyjności przedsiębiorstwa w warunkach globalizacji, TNOIK, Toruń 2002.

stat.gov.pl/metainformacje/slownik-pojec/pojecia-stosowane-w-statystyce-publicznej/770, pojecie.html

Willcocks L.P., Venters W., Whitley E.A., Cloud sourcing and innovation: slow train coming? „Strategic Outsourcing: An International Journal”, Vol. 6, No. 2, 2013.

Zacharia 7.G., Sanders N.R., Nix N.W., The Emerging Role of the Third Party Logistics Provider (3PL) as an Orchestrator, „Journal of Business Logistics” 32(1), 2011.

\section{International Competitiveness of Demand Networks: Innovation through Cloud Computing}

In today's economy supply chains are frequently transforming into international demand networks. Cloud computing is the answer to the main challenges posed by creation and management of flexible and adaptive global demand networks. Cloud computing is a tool that forms a link between technology and business, and 
thus innovatively improves competitiveness of international supply chains while supporting development of individual economic entities regardless of their size and scale of activities. Cloud computing is the basis for the development of the economy of sharing, mass customization, social networks, systems infrastructure and communications of individual companies and those of international supply chains. The article presents the possibilities of using cloud computing in supporting development of innovation in management of international demand networks. The article elaborates on whether cloud computing is an innovation, or rather just a tool to introduce innovations and what is the extent of the impact of its use on the level of innovation in international demand networks.

Keywords: demand network, cloud computing, innovation in demand network management

\section{Compétitivité internationale du réseau de la demande - l'innovation par le cloud computing}

Dans la conjoncture économique actuelle, les réseaux internationaux de la demande remplacent de plus en plus souvent des chaînes d'approvisionnement. Le cloud computing fait face aux défis de la création et de la gestion des réseaux mondiaux de la demande avec des structures souples et adaptatives répondant aux attentes des consommateurs. C'est une solution qui, étant un lien particulier entre la technologie et les affaires, combine de manière novatrice la problématique d'amélioration de la compétitivité des chaînes d'approvisionnement internationales tout en soutenant le développement des entités économiques individuelles indépendamment de leur taille et de leur échelle d'opération. Le cloud computing est la base du développement de l'économie du partage, de la personnalisation de masse, de tous les réseaux sociaux ainsi que des systèmes d'infrastructure informatique et de communication des entreprises individuelles et des chaînes d'approvisionnement internationales mentionnées ci-dessus. Le texte présente les possibilités d'utiliser le cloud computing pour soutenir le développement de l'innovation dans la gestion des réseaux internationaux de la demande. Larticle aborde la question de savoir si le cloud computing est une innovation ou plutôt un outil de mise en œuvre de l'innovation et quelle est l'ampleur de l'impact de son utilisation sur le niveau d'innovation dans les réseaux internationaux de la demande.

Mots-clés: réseaux de la demande, cloud computing, innovations dans la gestion des réseaux de la demande 


\section{Международная конкурентоспособность сети спроса - инновации посредством облачных вычислений}

В современшых экономических условиях цепочки поставок все чаще замепяптся международными сетями спроса. Главный вызов состоит в создапии и управлении глобальными сетями спроса с гибкими и адаптивными структурами, которые отвечают ожиданиям потребителей. Решением является внедрение облачных вычислений. Это инструмент, который будучи своего рода связующим звеном между технологией и бизнесом, новаторски объединяет повыпение конкурентоспособности международной цепи поставок, одновременно поддерживая развитие отдельных экономических субъектов независимо от их маспгтаба. Облачные вычисления являются основой для развития экономики совместного потребления, массовой кастомизации, всех социальных сетей, а также инфраструктуры ИТ и коммуникаций отдельных компаний и международных цепочек поставок. В роботе представлены возможности использования облачных вычислений с целью поддержки развития иншоваций в управлении международными сетями спроса. В статье анализируется, являются ли облачные вычисления инновацией или, скорее, инструментом для внедрения инноваций и какова степень их влияния на уровень инноваций в международных сетях спроса.

Ключевые слова: сети спроса, облачные вычисления, инновации в управлении цепочками спроса 